\title{
Helicobacter pylori: Primary susceptibility to clarithromycin in vitro in Nova Scotia
}

Linda M Best BSc, David JM Haldane MD, Gregory S Bezanson PhD, Sander JO Veldhuyzen van Zanten MD PhD

LM Best, DJM Haldane, GS Bezanson, SJO Veldhuyzen van Zanten. Helicobacter pylori: Primary susceptibility to clarithromycin in vitro in Nova Scotia. Can J Gastroenterol 1997; 11(4):298-300. Resistance to antimicrobial agents is a major determinant of the efficacy of regimens to eradicate Helicobacter pylori. Clarithromycin (CLA) has become one of the most commonly used antibiotics for treatment of $\mathrm{H}$ pylori infection. In this study, the rate of primary resistance to CLA in H pylori isolated from patients was determined. One hundred sixty-two strains were recovered from patients before treatment. Strains were grown and inoculated onto Mueller-Hinton agar with 7\% sheep blood. CLA epsilometer gradient agar diffusion test (E test) strips were used to test for susceptibility. Appropriate control organisms were tested to validate the assay. Plates were incubated at $37^{\circ} \mathrm{C}$ in a microaerophilic atmosphere for up to five days. E test results were easy to interpret. Strains were considered resistant if the minimum inhibitory concentration (MIC) was $2 \mu \mathrm{g} / \mathrm{mL}$ or greater. Three strains were resistant (two strains with MIC $8 \mu \mathrm{g} / \mathrm{mL}$ and one strain with MIC $12 \mu \mathrm{g} / \mathrm{mL}$ ), and 159 strains were sensitive (MICs ranged from less than 0.016 to $0.38 \mu \mathrm{g} / \mathrm{mL}$ ). Ninety per cent of the strains had MICs of $0.023 \mu \mathrm{g} / \mathrm{mL}$. Primary resistance was $1.8 \%$. These susceptibility data support the use of CLA for the treatment of H pylori in the Nova Scotia population.

Key Words: Clarithromycin, Helicobacter pylori

\section{Helicobacter pylori : sensibilité à la clarithromycine in vitro}

RÉSUMÉ : La résistance aux agents antimicrobiens est un facteur déterminant de l'efficacité des schémas visant l'éradication d'Helicobacter pylori. La clarithromycine est devenue l'un des antibiotiques les plus couramment utilisés en traitement de l'infection à $H$. pylori. Dans cette étude, le taux de résistance primaire à la clarithromycine manifestée par des isolats de $H$. pylori provenant de patients a été mesuré. Cent soixante-deux souches provenant de patients avant leur traitement ont été analysées. Les souches ont été mises en croissance, puis inoculées sur une gélose Mueller Hinton avec sang de mouton à $7 \%$. Des bandelettes de test $\mathrm{E}$ ont été utilisées pour vérifier la sensibilité des isolats. Les organismes pathogènes témoins appropriés ont servi à valider les analyses. Les plaques ont été mises en incubation à $37^{\circ} \mathrm{C}$ dans une atmosphère microaérophile pendant jusqu'à cinq jours. Les résultats du test $\mathrm{E}$ ont été faciles à interpréter. Les souches étaient résistantes si la concentration minimale inhibitrice (CMI) était d'au moins $2 \mu \mathrm{g} / \mathrm{mL}$. Trois souches se sont révélées résistantes, les CMI de $8 \mu \mathrm{g} / \mathrm{mL}(\mathrm{n}=2)$ et CMI $12 \mu \mathrm{g} / \mathrm{mL}(\mathrm{n}=1)$ et 159 souches ont été sensibles (éventail 0,016 à $0,38 \mu \mathrm{g} / \mathrm{mL}$ ). Quatre-vingt-dix pour cent des souches avaient des CMI de $0,023 \mu \mathrm{g} / \mathrm{mL}$ ou moins. Le taux de résistance primaire a été de 1,8\%. Ces données sur la sensibilité appuient l'emploi de la clarithromycine dans le traitement de H. pylori au sein de la population néo-écossaise.
$\mathrm{H}_{\mathrm{a}}^{\mathrm{c}}$ elicobacter pylori is associated with gastritis, duodenal and gastric ulcers, and gastric cancer. Successful treatment of $H$ pylori infection cures gastritis and ulcer disease, and may prevent $H$ pylori-associated gastric cancer (1-3). Eradication is difficult because many of the organisms reside deep in the protective gastric mucosal layer, where it is difficult to achieve bactericidal antibiotic concentrations. An important reason for treatment failure is primary or acquired resistance to one or more of the antibiotics.

The most successful regimens to eradicate $H$ pylori use a

Departments of Medicine (Gastroenterology) and Microbiology, Queen Elizabeth II Health Sciences Centre, Victoria General Hospital Site, Dalhousie University, Halifax, Nova Scotia

Correspondence and reprints: Ms LM Best, Centre for Clinical Research, 5788 University Avenue, Room 316, Halifax, Nova Scotia B3H 1V8.

Telephone 902-473-3369, fax 902-473-4432, e-mail lbest@ns.sympatico.ca

Received for publication December 12, 1996. Accepted February 17, 1997 


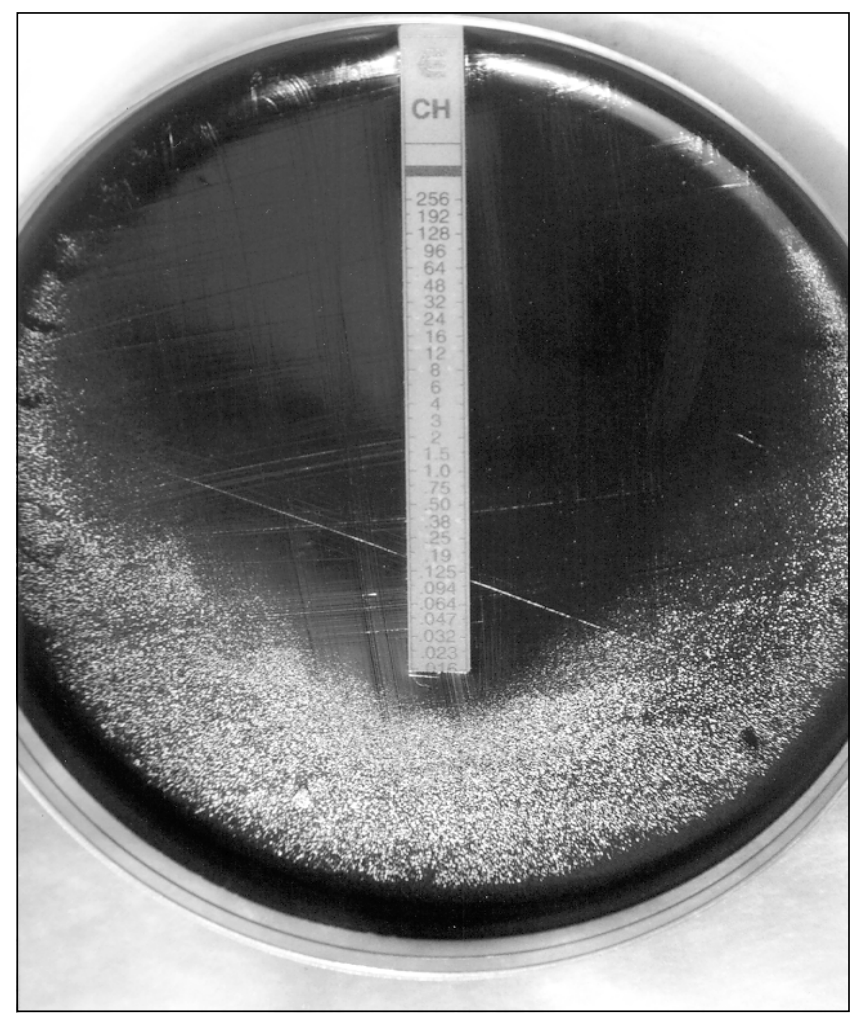

Figure 1) Epsilometer test results with a strain of Helicobacter pylori that is susceptive to clarithromycin at a minimum inhibitory concentration of less than $0.016 \mu \mathrm{g} / \mathrm{mL}$

proton pump inhibitor or a bismuth compound with two antimicrobials (4-7). Of the currently used antibiotic regimens, those that include clarithromycin (CLA) are most effective with cure rates exceeding $90 \%$ (7-10). The failure of CLA treatment regimens is primarily the result of infection with CLA-resistant strains of $H$ pylori $(11,12)$.

Antibiotic susceptibility tests demonstrate, under defined in vitro conditions, the minimum inhibitory concentration (MIC) at which an agent will inhibit the growth of bacteria. MIC values are used to predict in vivo sensitivity or resistance of organisms. The National Committee for Clinical Laboratory Standards has not yet published a reference antimicrobial susceptibility testing method for $\mathrm{H}$ pylori. CLA epsilometer gradient agar diffusion tests (E tests, AB Biodisk, Solna, Sweden) and agar dilution tests yield comparable CLA results, but $\mathrm{E}$ tests result in better discrimination between sensitive and resistant strains, are easier to perform and are widely used to determine MIC values (13-17).

The objective of our study was to determineMIC and rate of primary resistance to CLA in strains of $\mathrm{H}$ pylori isolated from our patient population.

\section{PATIENTS AND METHODS}

Patients: One hundred and sixty-two pretreatment strains of H pylori, from patients seen at the Victoria General Hospital Site, Queen Elizabeth II Health Sciences Centre, Halifax, Nova Scotia, were tested. All patients had endoscopically proven gastric or duodenal ulcers or nonulcer dyspepsia. Bi-

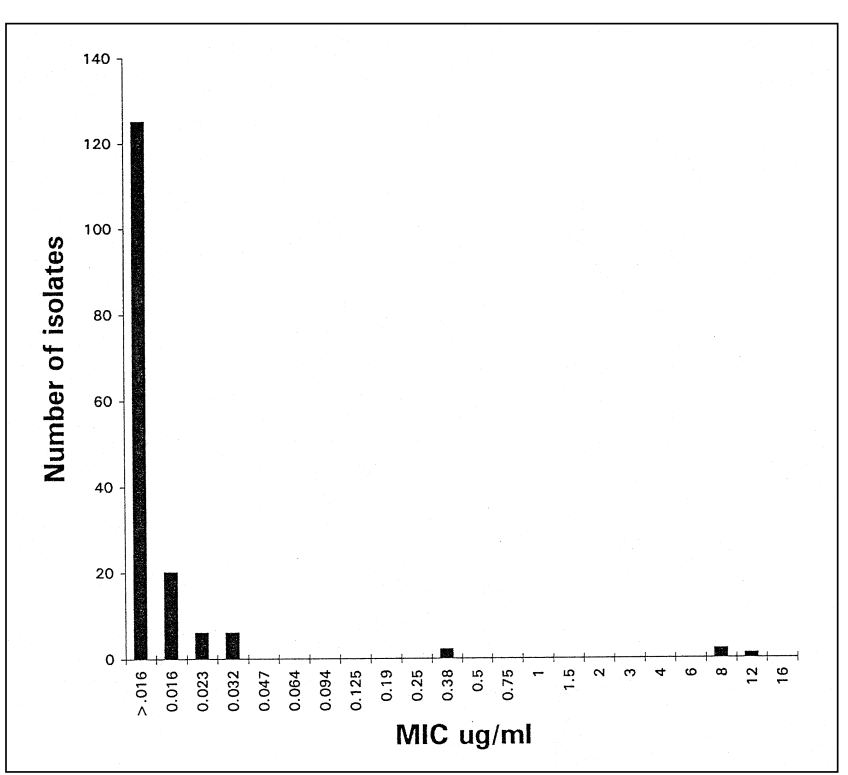

Figure 2) Three strains of Helicobacter pylori had minimum inhibitory concentrations (MIC) greater than $2 \mu \mathrm{g} / \mathrm{mL}$, which is the cutoff value for clarithromycin (CLA) susceptibility. Three (1.8\%) of $162 \mathrm{H}$ pylori strains were resistant to CLA. MIC of $90 \%$ of the strains was $0.023 \mu \mathrm{g} / \mathrm{mL}$ or less

opsies were cultured on Wilkins-Chalgren agar (Oxoid) with $7 \%$ sheep blood, identified by morphological and biochemical tests and frozen at $-20^{\circ} \mathrm{C}$ in porcine mucin. Patients were between 16 and 93 years of age. This was a retrospective study, and previous treatment with macrolide antibiotics was not assessed.

Susceptibility testing: The $\mathrm{H}$ pylori strains, frozen at $-20^{\circ} \mathrm{C}$ in porcine mucin, were subcultured to Mueller-Hinton (Oxoid) agar with $7 \%$ sheep blood and incubated at $37^{\circ} \mathrm{C}$ under humid, microaerophilic (5\% oxygen, $85 \%$ nitrogen, $10 \%$ carbon dioxide) conditions for four days. E tests were carried out according to the manufacturer's instructions. A cotton tipped swab was used to inoculate each $\mathrm{H}$ pylori strain into Brucella broth with $5 \%$ fetal calf serum. Turbidity was adjusted to yield $10^{7}$ to $10^{8}$ colony-forming units per $\mathrm{mL}$. A fresh swab was dipped into the suspension, squeezed out and streaked in three directions on Mueller Hinton agar with 7\% sheep blood (MHB). The plates were allowed to dry under microaerophilic conditions before carefully adding E test strips with a MIC range of 0.016 to $256 \mu \mathrm{g} / \mathrm{mL}$. The plates were incubated as above and interpreted according to the manufacturer's instructions on the second, third, fourth and fifth days. When bacterial growth was distinctly visible, MIC was calculated from the point of intersection between the zone edge and the E test strip, with care taken to assess diffuse endpoints, mutant colonies and resistance. H pylori strains with a CLA MIC $2 \mu \mathrm{g} / \mathrm{mL}$ or less were considered resistant (11).

The control strains American Type Culture Collection (ATCC) 29212 Streptococcus pneumoniae (defined range CLA MIC 0.03 to $0.12 \mu \mathrm{g} / \mathrm{mL}$ ) and ATCC 49247 Haemophilis influenzae (CLA MIC 4 to $16 \mu \mathrm{g} / \mathrm{mL}$ ), were suspended in Brucella broth, turbidity was adjusted as above, and a fresh 
swab was used to streak $S$ pneumoniae on MHB plates and $H$ influenzae on Haemophilus test plates. Control plates were allowed to dry before adding $\mathrm{E}$ test strips and incubating $S$ pneumoniae aerobically at $37^{\circ} \mathrm{C}$ and $\mathrm{H}$ influenzae in $5 \%$ carbon dioxide at $37^{\circ} \mathrm{C}$. MICs were determined, as above, after $24 \mathrm{~h}$.

\section{RESULTS}

CLA MICs obtained with the ATCC control strains were within the defined ranges.

E tests were easy to perform and easy to read despite the translucent nature of $H$ pylori (Figure 1). Growth was visible after two days, and clearly defined MIC endpoints were observed and recorded after three days. The endpoints did not change with additional incubation.

Three $\mathrm{H}$ pylori strains were resistant (1.8\%) and 159 were sensitive $(98.2 \%)$, and MICs of $90 \%$ of the strains were $0.023 \mu \mathrm{g} / \mathrm{mL}$ or less (Figure 2).

\section{DISCUSSION}

CLA is one of the most effective antibiotics for treatment of $\mathrm{H}$ pylori infection (7-10). It is a macrolide antibiotic that inhibits bacterial RNA-dependent protein synthesis and has a similar antimicrobial spectrum to erythromycin, but is more acid-stable and has better tissue penetration and fewer gastrointestinal side effects (18).

CLA is rapidly absorbed in the gastrointestinal tract, is

\section{REFERENCES}

1. Blaser MJ, Perez-Perez GI, et al. Infection with Helicobacter pylori strains possessing cag $\mathrm{A}$ is associated with an increased risk of developing adenocarcinoma of the stomach. Cancer Res 1995;55:2111-5.

2. NIH Consensus Statement. Helicobacter pylori in peptic ulcer disease. JAMA 1994;272:65-9.

3. Veldhuyzen van Zanten SJO, Sherman PM. Helicobacter pylori infection as a cause of gastritis, duodenal ulcer, gastric cancer and nonulcer dyspepsia: a systematic overview. Can Med Assoc J 1994;150:177-85

4. Graham DY, Lew GM, Malaty HM. Factors influencing the eradication of Helicobacter pylori with triple therapy. Gastroenterology 1992;102:493-6.

5. Moayyedi P, Tompkins DS, Axon ATR. Determination of the optimum dose of omeprazole in a new triple therapy regimen for eradicating Helicobacter pylori. Gut 1994;35:S16.

6. Al Assi MT, Ramirez FC, Lew GM, Genta RM, Graham DY. Clarithromycin, tetracycline, and bismuth: a new non-metronidazole therapy for Helicobacter pylori infection. Am J Gastroenterol 1994;89:203-5.

7. Lind T, Veldhuyzen van Zanten SJO, Unge P, et al. The MACH 1 study: optimal one-week treatment for $\mathrm{H}$ pylori defined? Gut 1995;37:A15.

8. Peterson WL, Graham DY, Marshall BJ, Blaser MJ, et al. Clarithromycin for eradication of Helicobacter pylori: a randomized double blind study. Am J Gastroenterol 1993;88;860-4.

9. Logan RPH, Gummett PA, Schaufelberger HD, et al. Eradication of Helicobacter pylori with clarithromycin and omeprazole. Gut 1994;35:323-6.

10. Lamouiliatte $H$, Cayla R, Forestier S, et al. Dual therapy versus triple therapy: high dose of lansoprazole plus amoxicillin in combination or stable in gastric acid, has a long half-life and is well tolerated (18). Used in combination with omeprazole, the antibiotic concentration in the antral mucosa and mucus layer appears to increase significantly (19).

For $H$ pylori susceptibility testing, E tests have yielded results that are equivalent to, but more precise than, agar dilution and disk diffusion results (13-17). The E test strip effectively diffuses a continuous concentration gradient of an antimicrobial agent into the agar medium and indicates the MIC where the zone of inhibition intersects the strip. The precision and simplicity of the test have led to its widespread use.

CLA resistance appears occurs because of point mutations in $23 \mathrm{~S}$ rRNA, which alter the ribosomal target (20). In countries where macrolide antibiotics are commonly used, CLA resistance ranges from $2 \%$ to $60 \%$ and is increasing $(11,12)$. Therefore, it is important to monitor closely susceptibility to observe any increase in primary resistance and to ensure that CLA is being used to treat only CLA-sensitive strains. Recently, we identified two patients who did not respond to triple therapy with omeprazole, metronidazole and CLA. The primary $H$ pylori cultures from both patients were CLA-sensitive, but post-treatment CLA MICs were greater than $256 \mu \mathrm{g} / \mathrm{mL}$.

Primary CLA resistance in $\mathrm{H}$ pylori strains is currently $1.8 \%$ for our population. These data support the use of CLA for treatment of H pylori in Nova Scotia.

not with clarithromycin for Helicobacter pylori infection. Gut 1995;37(Suppl 1):A43.

11. Glupczynski Y, Goutier S, Van den Borre C, Butzler JP, Burette A. Surveillance of Helicobacter pylori resistance to antimicrobial agents in Belgium from 1989 to 1994. Gut 1995;37:A223.

12. Cayla R, Zerbib F, Talbi P, Mégraud F, Lamouliatte H. Pre and post-treatment clarithromycin resistance of Helicobacter pylori strains: a key factor of treatment failure. Gut 1995;37:A217.

13. Sanchez ML, Jones RN. E test, an antimicrobial susceptibility testing method with broad clinical and epidemiologic applications. Antimicrobic Newsletter 1993;8:1-8.

14. Glupczynski Y. Culture of Helicobacter pylori from gastric biopsies and antimicrobial susceptibility testing. In: Lee A, Mégraud F, eds. Helicobacter pylori: Techniques for Clinical Diagnosis \& Basic Research. London: WB Saunders, 1996:17-32.

15. Cederbrant G, Kahlmeter G, Ljungh A. The E test for antimicrobial susceptibility testing of Helicobacter pylori. J Antimicrob Chemother 1993;31:65-71.

16. Glupcyznski Y, Labbe M, Hansen W, Crokaert F, Yourassowsky E. Evaluation of the E test for quantitative antimicrobial susceptibility testing of Helicobacter pylori. J Clin Microbiol 1991;29:2072-5.

17. Hirschl AM, Hirschl MM, Rotter ML. Comparison of three methods for the determination of the sensitivity of Helicobacter pylori to metronidazole. J Antimicrob Chemother 1993;32:45-9.

18. Neu HC. The development of macrolides: clarithromycin in perspective. J Antimicrob Chemother 1991;27(Suppl A):1-9.

19. Gustavson LE, Kaizer JF, Mukherjee DX, DeBartolo M, Schneck DW. Evaluation of pharmokinetic drug interactions between clarithromycin (c) and omeprazole (o). Am J Gastroenterol 1994;89:A1373.

20. Versalovic J, Kibler K, Small S, Graham DY, Go MF. Mutations in 23S ribosomal RNA confer clarithromycin resistance in Helicobacter pylori. Gut 1995;37:A266. 


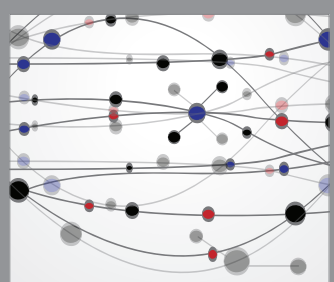

The Scientific World Journal
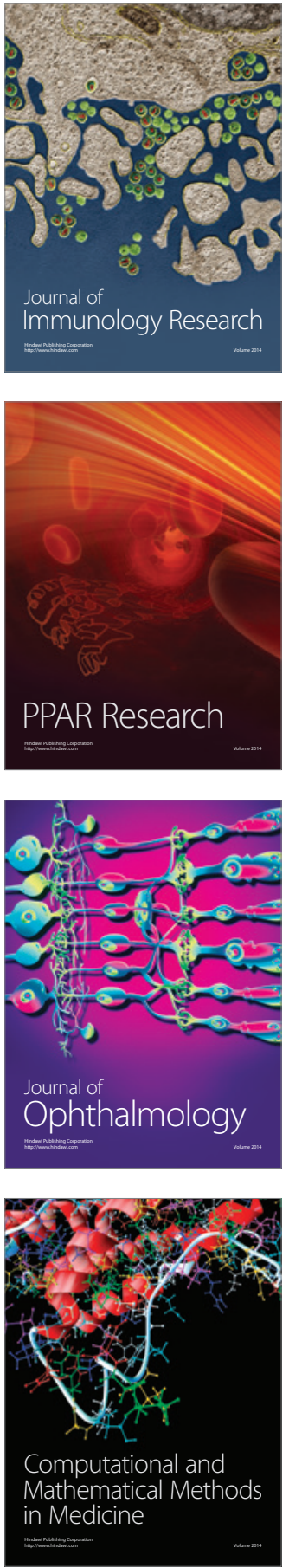

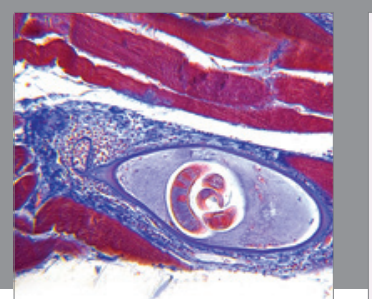

Gastroenterology Research and Practice

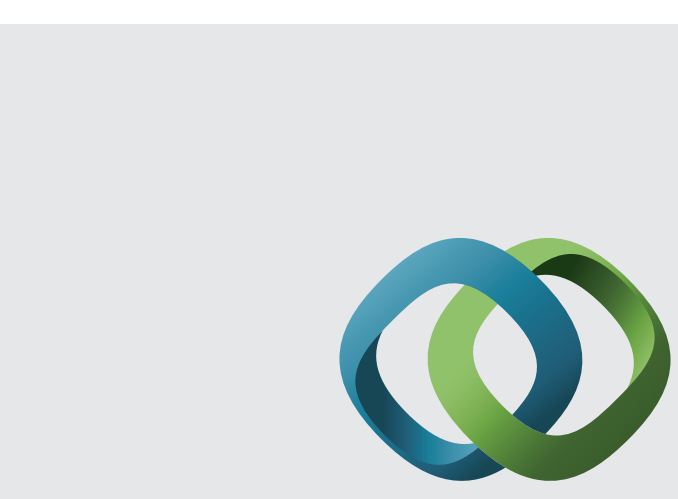

\section{Hindawi}

Submit your manuscripts at

http://www.hindawi.com
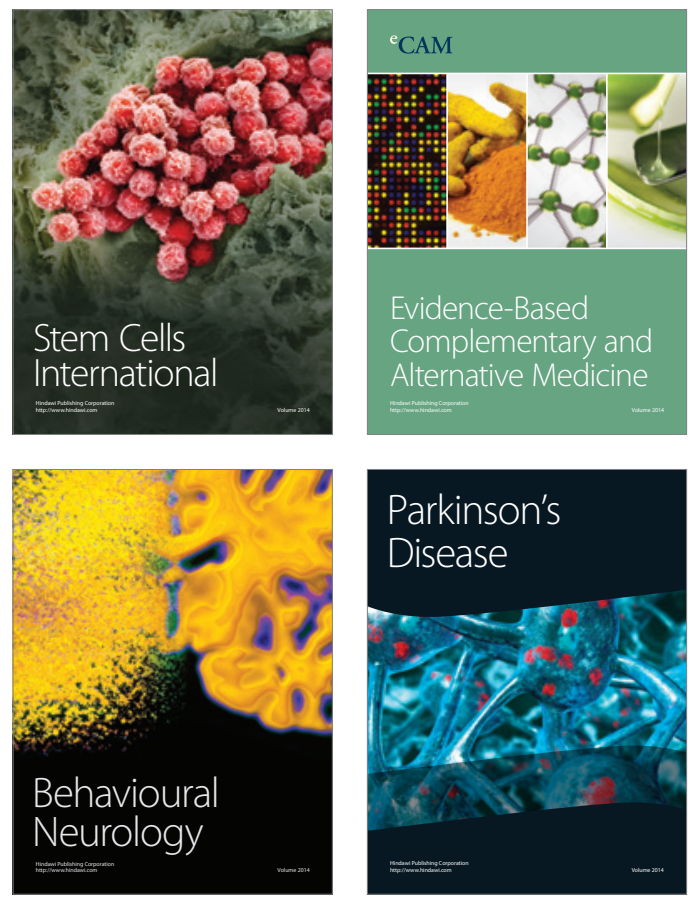
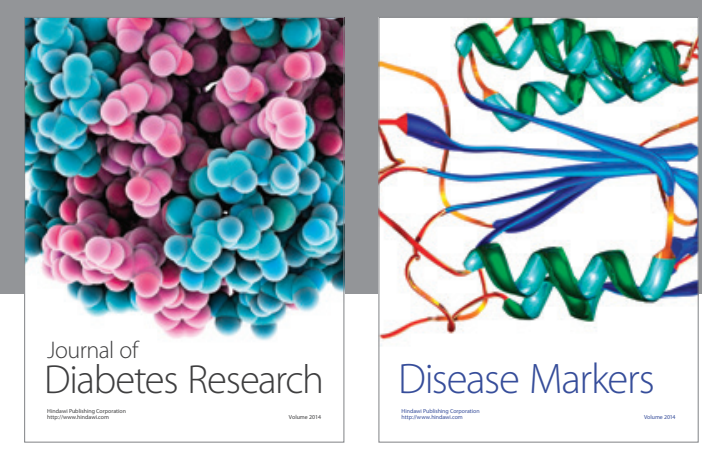

Disease Markers
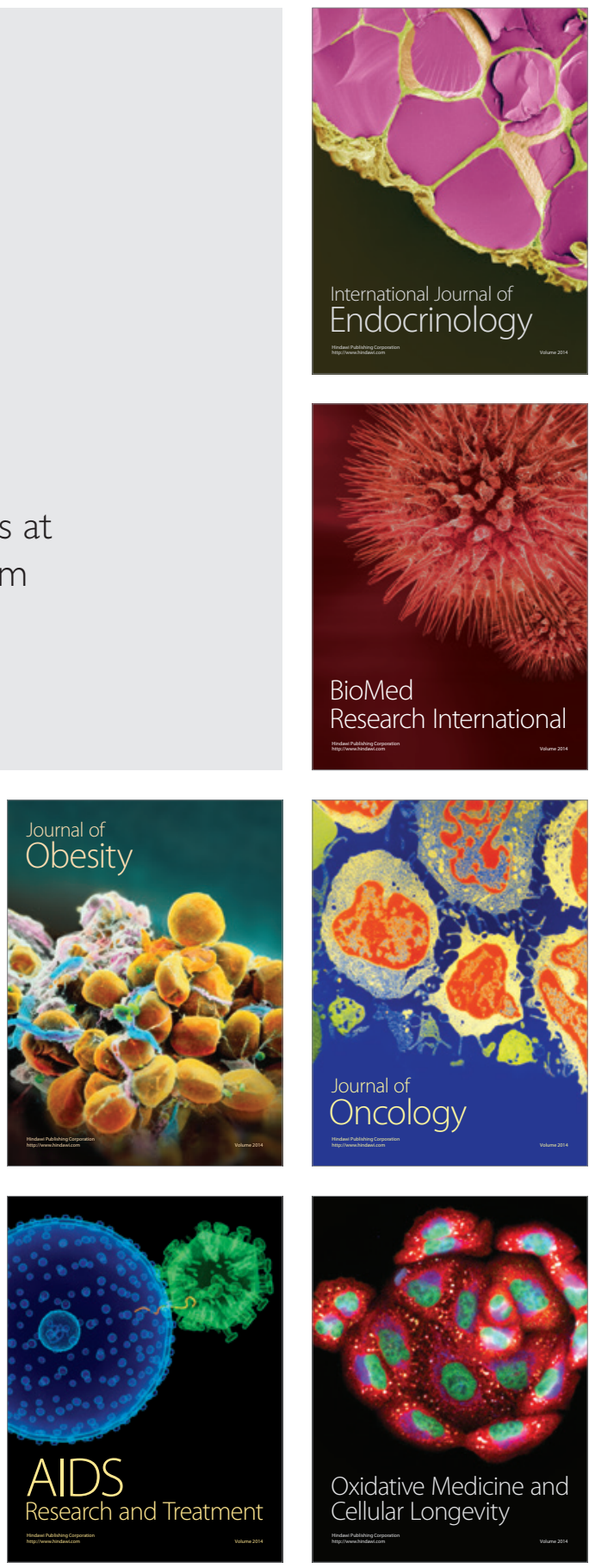